\title{
Does dieting make you fat?
}

\author{
Andrew J. Hill* \\ Academic Unit of Psychiatry and Behavioural Sciences, School of Medicine, University of Leeds, 15 Hyde Terrace, \\ Leeds LS2 9LT, UK
}

\begin{abstract}
Dieting Makes You Fat, the title of a 1980s book on weight control, is a popularised paradox, conveying a conclusion that is consistent with personal experience and the reported failure of most dietary approaches in the treatment of obesity. Few studies have been designed specifically to test this association. Yet there are prospective data showing that baseline dieting or dietary restraint increases the risk of weight gain, especially in women. Metabolic adaptations and the disinhibited eating of restrained eaters have been the most commonly cited explanations for such weight gain. Dietary restraint has also been implicated in the development and persistence of binge eating. The present paper critically evaluates the evidence supporting this paradox and reaches a rather different conclusion.
\end{abstract}

Dieting: Obesity: Treatment of obesity

'Dieting makes you fat'. This extraordinary proposal was the title of a book published in the UK in 1983. Written with ample expert consultation, Cannon \& Einzig (1983) dedicated it to 'the scores of millions of people in the West who are fatter than they want to be, who have tried dieting, who have found that dieting does not work, and who want to know why.' A blend of personal experience, science and contemporary opinion, this was among the first books on non-dieting weight control. In many ways it was a book of its time. Publication coincided with the advent of an increasingly vocal anti-diet movement, the early signs of increasing adult obesity, and a change in focus from food and eating to physical activity and exercise.

The book's legacy is not its content, but a four-word paradox. It suggests that a behaviour intended to facilitate weight loss actually has the opposite effect. As such, it describes a bleak causal association congruent with an increasingly negative depiction of dieting. Research has associated dieting with negative psychological states, such as increases in depression and anxiety (Warren \& Cooper, 1988). Dieters have deficits in certain aspects of cognitive performance (Green \& Rogers, 1995). Dieters are also at increased risk of eating disorders (Patton et al. 1999), and even increased morbidity and mortality (Blair et al. 1993).

The evidence supporting these conclusions has been reviewed several times (e.g. Brownell \& Rodin, 1994; French \& Jeffery, 1994; Gregg \& Williamson, 2002). While not fully absolved, dieting appears to have been given a broad safety certificate. Nevertheless, the welldocumented failure of most dietary approaches in the treatment of obesity, in conjunction with personal experience of the difficulties of energy-deficit diets, has done little to enhance the reputation of dieting.
Nor has the diet industry done much to raise consumer confidence. Two reports published recently, intended for the diet industry itself, make interesting, if expensive, reading. Retailing at nearly $\$ 2000$ and $\$ 5000$ respectively, they reveal an annual turnover of $\$ 39$ billion in the US diet industry (MarketData, 2002), and $€ 93$ billion in the equivalent European industry in 2002 (Datamonitor, 2003). Headline statements include, 'In 2002, 231 million Europeans attempted some form of diet. Of these only $1 \%$ will achieve permanent weight loss.' A degree of cynicism appears justified. The size of the diet industry has grown commensurate with the rise in population obesity. The previous quotation confirms that the products sold by the diet industry are known to be ineffective. Indeed, a newcomer to this area may be justified in concluding that industry is contributing to the problem. From a purely business perspective, a diet industry that marketed products yielding safe and sustainable weight loss would commit long-term financial suicide. Moreover, the diet industry is one of several major and global concerns, including agriculture, pharmaceuticals, and the food industry itself, that make a profit out of obesity (Nestle, 2003). For the diet industry to regain the trust of consumers (Datamonitor, 2003), a great deal of effort is required to counter Cannon's paradox.

\section{Dieting and weight change}

Cross-sectional studies say little about the causal association between dieting and weight change. Prospective studies can be more informative, but few have been designed specifically to test this association. Table 1 summarises the outcomes of investigations that have used data collected from special cohorts or that have addressed this association directly. All but one of the nine studies 
Table 1. Prospective studies showing the relationship between dieting or dietary restraint and weight change

\begin{tabular}{|c|c|c|c|}
\hline Authors & Cohort & Time period & Outcome \\
\hline French et al. (1994) & $\begin{array}{l}\text { Healthy Worker Project: } 3553 \text { adults } \\
\text { in smoking-cessation and } \\
\text { weight-control worksite intervention }\end{array}$ & 2 years & $\begin{array}{l}\text { Baseline dieters gained approximately } \\
1 \mathrm{~kg} \text { more than non-dieters (women only) }\end{array}$ \\
\hline McGuire et al. (1999) & $\begin{array}{l}\text { National Weight Control Registry: } 714 \\
\text { successfully maintaining } \\
\text { weight losers }\end{array}$ & 1 year & $\begin{array}{l}\text { Baseline dieting one of several predictors } \\
\text { of weight gain }\end{array}$ \\
\hline Korkeila et al. (1999) & $\begin{array}{l}\text { Finnish Twin Cohort: } 7729 \text { members } \\
\text { of twin pairs }\end{array}$ & 6 and 15 years & $\begin{array}{l}\text { Baseline dieters had two times the risk of } \\
\text { major weight gain }(>10 \mathrm{~kg} \text { ) than non-dieters } \\
\text { (younger men and women aged } 30 \text { years only) }\end{array}$ \\
\hline Juhaeri et al. (2001) & $\begin{array}{l}\text { Atherosclerosis Risk in Communities } \\
\text { (ARIC) study: } 10554 \text { white and } \\
\text { African American adults }\end{array}$ & 6 years & $\begin{array}{l}\text { Baseline dieters gained approximately } \\
0.5 \mathrm{~kg} / \text { year more than non-dieters }\end{array}$ \\
\hline Drapeau et al. (2003) & $\begin{array}{l}\text { Quebec Family Study: subsample of } \\
75 \text { adults }\end{array}$ & 6 years & $\begin{array}{l}\text { Baseline TFEQ, dietary restraint associated } \\
\text { with weight gain (women only) }\end{array}$ \\
\hline Klesges et al. (1989) & Young adults $(n 65)$ & $\begin{array}{l}8 \mathrm{~d} \text { (US } \\
\text { Thanksgiving holiday) }\end{array}$ & $\begin{array}{l}\text { Baseline dietary restrained gained more } \\
\text { weight than non-restrained }\end{array}$ \\
\hline Klesges et al. (1991) & Young adults ( $n$ 305) & 2 years & $\begin{array}{l}\text { Baseline dietary restraint not related } \\
\text { to weight change }\end{array}$ \\
\hline Klesges et al. (1992) & $\begin{array}{l}\text { Adults in study of cardiovascular } \\
\text { risk ( } n \text { 287) }\end{array}$ & 1 year & $\begin{array}{l}\text { Baseline dietary restraint a predictor } \\
\text { of weight gain (women only) }\end{array}$ \\
\hline Stice et al. (1999) & Adolescent girls ( $n$ 692) & 3 years & $\begin{array}{l}\text { Baseline dietary restraint (two times risk) and } \\
\text { dieting (three times risk) predictors of } \\
\text { obesity onset }\end{array}$ \\
\hline
\end{tabular}

TFEQ, three-factor eating questionnaire.

included show that baseline dieting or dietary restraint was associated with increased risk of weight gain, sometimes exclusively in women. The magnitude of risk is rather modest, amounting to an approximate greater gain of $0.5 \mathrm{~kg}$ per year or, in predictive models, a doubling of risk compared with non-dieters. In fact, the only study to investigate obesity onset was that by Stice et al. (1999). On the face of it, this represents the clearest empirical evidence that dieting facilitates weight gain.

In terms of mechanisms to account for the failure of dieting to bring about weight loss (and that potentially also explain weight gain), two have been prominent. One concerns the alterations in metabolic rate and energy requirements associated with energy-deficient diets. Much has been made in the popular press regarding the degree and persistence of these physiological responses and their potential to facilitate post-dieting weight rebound and gain. Prentice et al. reviewed the issue in 1991 and reached conclusions that still hold more than 10 years later:

(1) BMR is rarely suppressed by more than $20 \%$;

(2) very-low-energy diets suppress metabolic rate more than moderate energy-deficit diets;

(3) physical exercise probably has a protective effect;

(4) after dieting BMR returns to a level commensurate with the new body size.

\section{Dietary restraint}

The second explanatory mechanism is inferred by the laboratory work on dietary restraint pioneered by Herman, Polivy and their colleagues. Take one of their recent studies as an example. A group of female undergraduate students was recruited to a study ostensibly about the effects of food deprivation on taste perception (Urbszat et al. 2002). Half of the participants were assigned to a diet condition and told that immediately after the study they would start on a $7 \mathrm{~d}$ low-fat, energy-reduced diet. Along with the diet plan was a list of forbidden foods. Participants were presented with three plates of cookies (one of the forbidden foods) that they had to taste and rate, and were left alone for 10 minutes with the instruction, 'help yourself ... we have tons.' Participants then completed a dietary restraint scale and the cookie plates were re-weighed.

The outcome is summarised in Fig. 1. Unrestrained female subjects were unresponsive to the diet manipulation. Restrained eaters ate least in the no-diet condition, but significantly more (than all three other groups) in the anticipated diet condition. This 'last supper effect' as a response to anticipated deprivation is just one example of the breakdown of dieting that has been described in this elegant and replicable research scenario. Disinhibition, or the loss of inhibition, is the term that describes this self-regulatory failure. The cognitive explanatory model borrowed from the addictions literature is the abstinence violation effect. Rigid and dichotomous thinking, in this

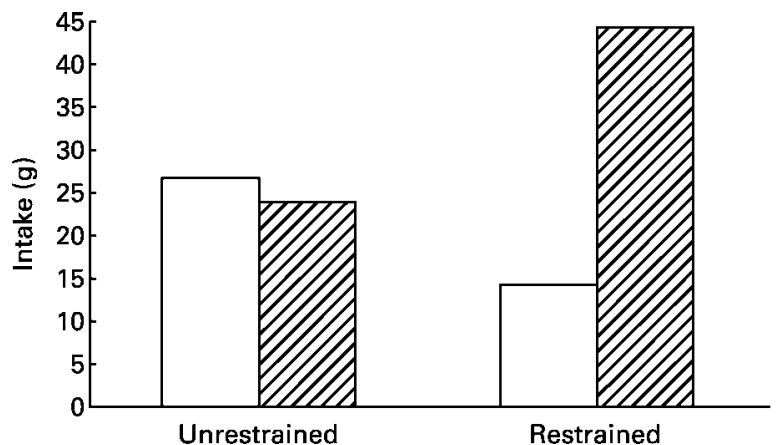

Fig. 1. Food intake by unrestrained and restrained eaters in a nodiet condition ( $\square$ ) and faced with starting a diet after the study (ש्थ). (Re-drawn from Urbszat et al. 2002.) 
case about eating, fosters catastrophising of a single lapse or the prospect of prolonged food deprivation. The 'what-the-hell' reasoning is familiar to most people in relation to a range of different substances. One of the triumphs of the dietary restraint literature has been the capacity to show the disinhibiting effects of a variety of factors ranging from negative effect, through social processes, to beliefs about the energy content of food.

The value of this literature has been augmented by the proposed association between dieting and binge eating (Polivy \& Herman, 1985). Disinhibited eating by restrained eaters has been argued as a laboratory analogue of binge eating: periods of dietary restriction alternating with episodes of uncontrolled overeating. Dieting is also implicated in the persistence of binge eating. Fairburn's cognitive model of maintenance, used in cognitive behavioural therapy for the disorder, places dieting at the centre, albeit rigid and intense dieting (Fairburn, 2002). Empirical research support, however, is a mixed affair with no clear support for an association, organising the studies either by methodology (cohort $v$. prospective studies) or clinical group (eating disorders, obesity). The one exception is research looking at binge-eating onset in adolescent girls. Two studies using statistical modelling have shown that dieting is one of several factors that are predictive of binge-eating psychopathology onset (Stice \& Agras, 1998; Stice, 2001). A third study has shown moderate dieters to be five times more likely than their non-dieting peers to develop an eating disorder, in nearly all cases partial syndrome bulimia nervosa (Patton et al. 1999).

\section{Convincing evidence?}

Any consideration of dieting engenders a huge emotional response, as it is clouded by people's own experience of failure and anticipated accusations of blame for their overweight (Hill, 2003). Accusing the diet industry of contributing to obesity may be one such expression. But just how convincing is the evidence presented earlier? Relating dieting to binge-eating onset is poor support for the contention that dieting leads to weight gain or obesity onset. Weight is an uncertain factor in this small literature. Indeed, Stice argues that dieting is merely a proxy for more important predictive variables in relation to eating disorders, let alone weight gain (Stice, 2002).

Laboratory studies of disinhibited eating by highly restrained individuals only hint at what might lead to weight gain. There is vigorous debate as to whether different restraint scales measure the same psychological tendency, and how this relates to weight-loss dieting. Dieting itself varies between studies in terms of its intensity, duration and application (Hill, 2002). Moreover, dieting is commonly part of a weight-loss package making partitioning of component contributions to weight change very difficult.

Perhaps most telling is a closer examination of the studies summarised in Table 1. Take, for example, the Finnish Twin cohort study (Korkeila et al. 1999). Detailed inspection of these twins showed that dieting aggregated in families, suggesting a familial predisposition to gain weight. The most parsimonious explanation is that this predisposition accounted for higher levels of dieting and ultimately overwhelmed weight-loss attempts. Similarly, examination of the study relating adolescent dieting to obesity onset (Stice et al. 1999) shows that exercise for weight control also predicted obesity onset. Indeed, all weight control methods were positively correlated with the girls' BMI at the start of the study.

Cannon's paradox is unlikely to be a paradox after all. The most obvious conclusion from this review is not that dieting makes you fat, but that being fat makes you (more likely to) diet. That the research literature fails to substantiate the success claimed by some weight-loss products should not lead us to reinforce a causal association that is naive and inaccurate. The assertion that dieting makes you fat fails to recognise that people who successfully control their weight are often misclassified as nondieters and that obesity causes dieting rather than vice versa. Most importantly, it underplays the roles of biology and the environment in the determination of weight gain and as barriers to sustained weight loss.

\section{References}

Blair SN, Shaten J, Brownell K, Collins G \& Lissner L (1993) Body weight change, all-cause mortality, and cause-specific mortality in the Multiple Risk Factor Intervention Trial. Ann Intern Med 119, 749-757.

Brownell KD \& Rodin J (1994) The dieting maelstrom: is it possible and advisable to lose weight? Am Psychol 49, 781-791.

Cannon G \& Einzig H (1983) Dieting Makes You Fat. London: Century Publishing.

Datamonitor (2003) Diet Watchers. http://www.datamonitor.com/ consumer/reports/product_summary.asp?pid = DMCM0341

Drapeau V, Provencher V, Lemieux S, Despres J-P, Bouchard C $\&$ Tremblay A (2003) Do 6-y changes in eating behaviours predict changes in body weight? Results from the Quebec Family Study. Int J Obes 27, 808-814.

Fairburn CG (2002) Cognitive-behavioural therapy for bulimia nervosa. In Eating Disorders and Obesity. A Comprehensive Handbook, 2nd ed., pp. 302-307 [CG Fairburn and KD Brownell, editors]. New York: The Guilford Press.

French SA \& Jeffery RW (1994) Consequences of dieting to lose weight: effects on physical and mental health. Health Psychol 13, 195-212.

French SA, Jeffery RW, Forster JL, McGovern PG, Kelder SH \& Baxter JE (1994) Predictors of weight change over 2 years among a population of working adults; The Healthy Worker Project. Int J Obes 18, 145-154.

Green MW \& Rogers PJ (1995) Impaired cognitive function during spontaneous dieting. Psychol Med 25, 1003-1010.

Gregg EW \& Williamson DF (2002) The relationship of intentional weight loss to disease incidence and mortality. In Handbook of Obesity Treatment, pp. 125-143 [TA Wadden and AJ Stunkard, editors]. New York: The Guilford Press.

Hill AJ (2002) Prevalence and demographics of dieting. In Eating Disorders and Obesity. A Comprehensive Handbook, 2nd ed., pp. 80-83 [CG Fairburn and KD Brownell, editors]. New York: The Guilford Press.

Hill AJ (2003) Self-image and the stigma of obesity. In Adult Obesity. A Paediatric Challenge, pp. 61-72 [LD Voss and TJ Wilkin, editors]. London: Taylor \& Francis.

Juhaeri, Stevens J, Chambless LE, Tyroler HA, Harp J, Jones D \& Arnett D (2001) Weight change among self-reported dieters 
and non-dieters in white and African American men and women. Eur J Epidemiol 17, 917-923.

Klesges RC, Isbell TR \& Klesges LM (1992) Relationship between dietary restraint, energy intake, physical activity, and body weight: a prospective analysis. J Abnorm Psychol 101, 668-674.

Klesges RC, Klem ML \& Bene CR (1989) Effects of dietary restraint, obesity and gender on holiday eating behaviour and weight gain. J Abnorm Psychol 98, 499-503.

Klesges RC, Klem ML, Epkins CC \& Klesges LM (1991) A longitudinal evaluation of dietary restraint and its relationship to changes in body weight. Addict Behav 16, 363-368.

Korkeila M, Rissanen A, Kaprio J, Sorensen TIA \& Koskenvuo M (1999) Weight-loss attempts and risk of major weight gain: a prospective study in Finnish adults. Am J Clin Nutr 70, 965-975.

McGuire MT, Wing RR, Hill JO, Klem ML \& Lang W (1999) What predicts weight gain in a group of successful weight losers? J Consult Clin Psychol 67, 177-185.

MarketData Enterprises (2002) The US Weight Loss and Diet Control Market, 7th ed. http://www.mkt-data-ent.com/diet.html Nestle M (2003) The ironic politics of obesity. Science 299, 781.

Patton GC, Selzer R, Coffey C, Carlin JB \& Wolfe R (1999) Onset of adolescent eating disorders: population based cohort study over 3 years. Br Med J 318, 765-768.
Polivy J \& Herman CP (1985) Dieting and bingeing: a causal analysis. Am Psychol 40, 193-201.

Prentice AM, Goldberg GR, Jebb SA, Black AE \& Murgatroyd PR (1991) Physiological responses to slimming. Proc Nut Soc 50, 441-458.

Stice E (2001) A prospective test of the dual-pathway model of bulimic pathology: mediating effects of dieting and negative affect. J Abnorm Psychol 110, 124-135.

Stice E (2002) Risk and maintenance factors for eating pathology: a meta-analytic review. Psychol Bull 128, 825-848.

Stice E \& Agras WS (1998) Predicting onset and cessation of bulimic behaviours during adolescence: a longitudinal grouping analysis. Behav Ther 29, 257-276.

Stice E, Cameron RP, Killen JD, Hayward C \& Barr Taylor C (1999) Naturalistic weight-reduction efforts prospectively predict growth in relative weight and onset of obesity among female adolescents. J Consult Clin Psychol 67, 967-974.

Urbszat D, Herman CP \& Polivy J (2002) Eat, drink, and be merry, for tomorrow we diet: Effects of anticipated deprivation on food intake in restrained and unrestrained eaters. $J$ Abnorm Psychol 111, 396-401.

Warren C \& Cooper PJ (1988) Psychological effects of dieting. Br J Clin Psychol 27, 269-270. 